\title{
Effects of operating parameters on efficiency of lead removal by complexation-microfiltration process
}

\author{
Katarina V. Trivunac, Slavica M. Stevanović \\ University of Belgrade, Faculty of Technology and Metallurgy, Belgrade, Serbia
}

\begin{abstract}
The majority of lead content found in the environment is a result of human activities. Heavy metals can be hazardous because they tend to bioaccumulate. A complexation-microfiltration process for the removal of $\mathrm{Pb}(\mathrm{II})$ ions was studied. The aim of microfiltration of the model wastewater containing heavy metal ions was to find an optimum ratio between the concentrations of the complexing agent and metal, and determining the most favorable $\mathrm{pH}$ value. The microfiltration experiments were carried out in a stirred dead-end cell. Diethylaminoethyl cellulose (DEAE 23) was selected as the complexing agent. Versapor membranes were used to separate formed polymer-metal complex. The concentration of heavy metal ions after microfiltration in aqueous solution was determined using atomic absorption spectroscopy (AAS). Effects on the amount of complexing agent, concentration of metal ion, $\mathrm{pH}$ value and operating pressure on the flux, $J$, and rejection coefficient, $R$, were investigated. Experimental results indicate that the $\mathrm{pH}$ of the solution has considerable influence on the rejection coefficient. An increase in $\mathrm{pH}$ and the amount of complexing agents enabled us to obtain a very high retention coefficient (99\%).
\end{abstract}

Keywords: complexation-microfiltration, lead removal, water treatment, diethylaminoethyl cellulose.

SCIENTIFIC PAPER

UDC 628.3.034.2:66.067.1

Hem. Ind. 66 (4) 461-467 (2012)

doi: 10.2298/HEMIND111122007T

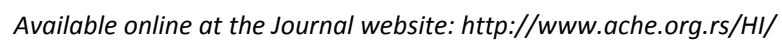

Lead is a highly toxic substance, exposure to which can produce a wide range of adverse health effects. Lead occurs naturally in the environment. However, most lead concentrations that are found in the environment are a result of human activities. A large proportion of the lead used today serves the automobile industry in components such as storage batteries, radiators and solder for joints. Lead is an important part of chemical tank liners and of radiation shields in telephone and power cable conduits. It also is used in solder for plumbing and some paints, especially those for ships where corrosion can be a significant problem. Bullets, pottery, crystal glassware, wire and stained glass windows all may require lead.

Heavy metals are dangerous because they tend to bioaccumulate. Lead is a cumulative toxicant causing chronic poisoning, therefore its removal from water is very important. Removal, separation and enrichment of heavy metal ions in aqueous solutions play an important role for environmental remediation of wastewater [1]. Among many separation techniques, membrane separation is an efficient and widely applied separation process. Heterogeneous methods have been used for the separation of inorganic ions [2]. Two-phase systems

Correspondence: K. Trivunac, Department of Analytical Chemistry and Quality Control, Faculty of Technology and Metallurgy, P.O. Box 494, Karnegijeva 4, 11120 Belgrade, Serbia.

E-mail: trivunac@tmf.bg.ac.rs

Paper received: 11 October, 2011

Paper accepted: 30 January, 2012 can be avoided by using separation methods based on pressure-driven membrane processes in the aqueous phase, such as microfiltration [3].

The efficient and selective separation of inorganic ions can be achieved by using water-soluble, polymeric reagents in combination with membrane filtration. This method uses water soluble polymers to bind metal ions from aqueous solutions [4]. A microfiltration membrane can retain metal-polymer complexes of sufficient molecular size and thus metal ions can be concentrated during microfiltration process for recovery or disposal. Since the complexation of metal ions with polymers take place in a homogeneous phase, problems encountered with multiphase separation are not observed [5]. Another advantage of this method is the lowenergy requirements involved. In addition, using different polymers can achieve selective metal recovery.

Katsoufidou et al. [6] investigated removal of divalent metal ions such as calcium (II) with alginate. Kawano et al. [7] studied binding equilibria of $\operatorname{poly}(\alpha$ -acethylaminoacrilic acid) with divalent ions. Kim and Lim [8] investigated removal of heavy metal ions from water by cross-linked carboxymethyl cornstarch; lead, cadmium and mercury ions in water were almost completely removed; copper concentration was reduced. Canizares et al. investigated the use of polyacrilic acid for selective separation of lead (II) and calcium (II) ions from water [9]. Polyethyleneimine was used as a watersoluble polymeric macroligand by several authors for selective separation of copper (II) and nickel (II) [10,11], 
for recovery of chromium [12,13], for selective separation of copper (II), nickel (II), zinc (II) and cadmium (II) [14]. Many authors used chitosan as macroligand in their researches [15-17]. Petrov and Nenov studied removal of copper from wastewater by complexing with carboxylmethyl cellulose [18]. Although many experiments have been done using different macroligands [19-22] able to complex heavy metal ions, the choice of water-soluble macroligands remains important for developing this technology. Cellulose, synthesized by many plants and bacteria, is one of the most abundant natural polymers in the biosphere. It is a carbohydrate polymer consists of repeating $\beta$-D-glucopyranose units that are linked covalently between the $\mathrm{OH}$ group of the C4 and C1 carbon atoms and does not dissolve in water or in many organic solvents. Native cellulose has a poor adsorption capacity and low physical stability because attachment of all three hydroxyls to the same ring may cause steric hindrance, and the hydroxyl groups are not easily accessible to chemical reactions due to the crystalline regions in the polymer matrix. Modification by chemical reactions can develop capacity of native cellulose for heavy metal ions [23]. DEAE-cellulose is a derivate of cellulose commonly used for ion-exchange chromatography containing an ionizable tertiary amine group and having less hydroxyls than native cellulose. The aim of the present study is to evaluate the applicability and the efficiency of DEAE 23 and effects of operating parameters on removal of lead ions from water by complexation-microfiltration process.

\section{EXPERIMENTAL}

All microfiltration experiments were performed in a stirred cell (Millipore 8050), in the apparatus shown in Figure 1. The cell was stirred at $300 \mathrm{rpm}$ by a magnetic motor, which was high enough but could prevent formation of a serious vortex in the cell. The pressure was controlled by nitrogen gas.

The research was conducted on wastewater model solutions containing $\mathrm{Pb}(\mathrm{II})$. Upon our previous work [24], diethylaminoethyl cellulose (DEAE 23) was selected as complexing agent. To separate formed polymer-metal ions complex, Versapor ${ }^{\circledR} 200$ membranes, with effective area of $0.00134 \mathrm{~m}^{2}$ were used. The feed volume of $25.0 \mathrm{~cm}^{3}$ concentration $50.0 \mathrm{mg} \mathrm{dm}^{-3}$ and desired DEAE 23 concentration were prepared and stirred for $1 \mathrm{~h}$ at room temperature before the filtration. Experiments with longer mixing time demonstrated that $1 \mathrm{~h}$ was sufficient to reach the complexation equilibrium. The $\mathrm{pH}$ was adjusted with $\mathrm{HCl}$ and $\mathrm{NaOH}$ solutions. The concentration of heavy metal ions in aqueous solution after microfiltration was determined using atomic absorption spectroscopy (Pye Unicam SP9, Philips) at $283.3 \mathrm{~nm}$.

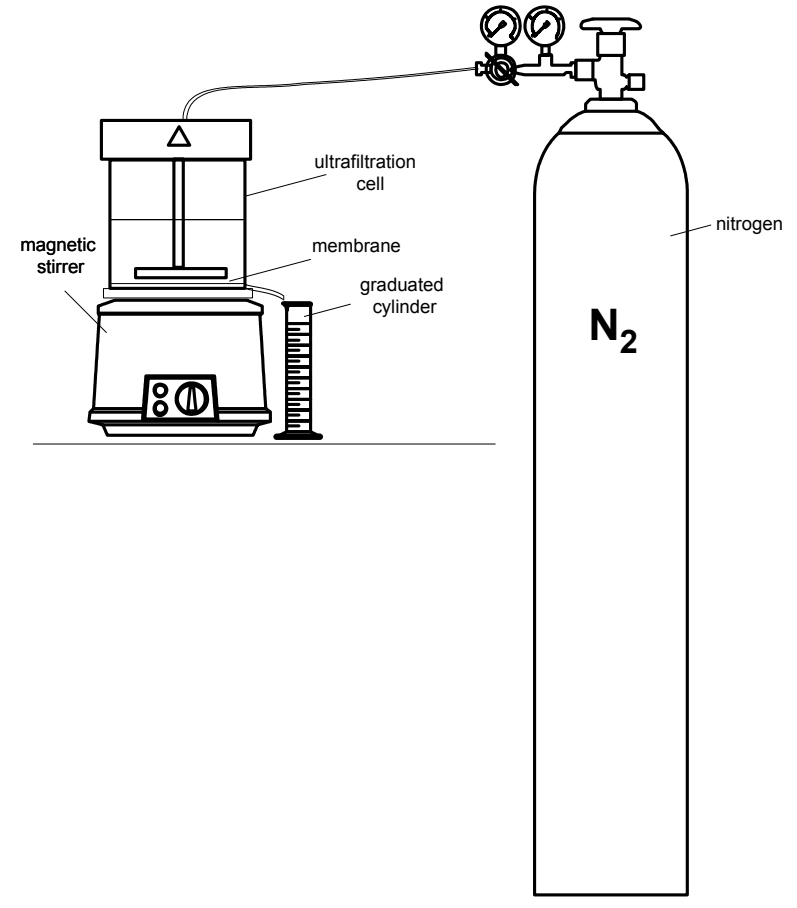

Figure 1. Apparatus for microfiltration process.

\section{RESULTS AND DISCUSSION}

Effects of pressure, pH value, amount of complexing agent, and concentration of metal ion on the flux and rejection coefficient were investigated.

The flux of solution containing $\mathrm{Pb}(\mathrm{II})$-ions was calculated as:

$J=\frac{V}{A \tau}$

where $V$ is volume of permeate, $A$ is effective membrane area and $\tau$ is time.

The rejection of $\mathrm{Pb}$-ions was calculated as:

$R=100\left(1-\frac{c_{\mathrm{p}}}{c_{\mathrm{f}}}\right)$

where $c_{p}$ and $c_{f}$ are concentrations of metal ions in permeate and feed, respectively.

\section{Effect of pressure}

The effect of applied pressure was investigated at fixed initial lead ion concentration of $50.0 \mathrm{mg} / \mathrm{dm}^{3}, \mathrm{pH}$ 9.0 and pressure of nitrogen in range $100-400 \mathrm{kPa}$.

The flux of solute is lowered from pure water. From the shape of the curve in Figure 2 it can be concluded that no sharp change in the curve of flux versus pressure is found whereas the flux also is still a slight function of pressure at higher pressure. This indicates that concentration polarization occurs but no plateau is reached so the gel-polarization effect is not dominant for polymer at pressure range studied. 


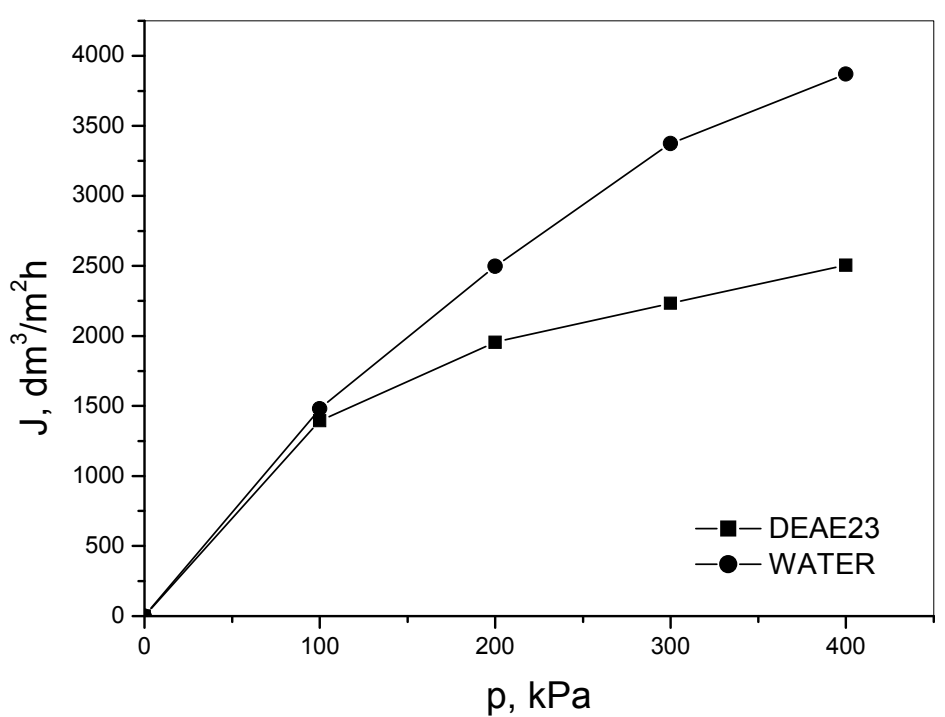

Figure 2. Effect of pressure on the flux (Versapor membrane, $c_{D E A E}=75 \mathrm{mg} \mathrm{dm}^{-3}$ ).

\section{Effects of $\mathrm{pH}$ and solute concentration}

The effects of $\mathrm{pH}$ on the flux and rejection of the metal ions from aqueous solutions using polyacrilic microfiltration membrane are shown in Figures 3 and 4, respectively. The studied $\mathrm{pH}$ range was from 5.0 to 9.0, and the applied pressure was $300 \mathrm{kPa}$. With the increase of concentration of $\mathrm{Pb}$ ions above $10.0 \mathrm{mg} / \mathrm{dm}^{3}$ flux slightly decrease as expected (Figure 3 ). It can be concluded that flux is almost unaffected by $\mathrm{pH}$.

Metal retention is related to metal complexation by the polymer. The main parameters influencing the complexation of given metal ion with a given polymers are linked to solution composition $(\mathrm{pH}$, polymer concentration, etc.). Other factors can also affect the metal retention, such as temperature, pressure and mem- brane type. The formation of metallic complexes with a ligand is $\mathrm{pH}$ dependent.

Amino group of diethylaminoethyl cellulose may react with $\mathrm{H}^{+}$according to:

$$
\mathrm{R}_{\mathrm{CE}}-\mathrm{N}\left(\mathrm{C}_{2} \mathrm{H}_{5}\right)_{2}+\mathrm{H}^{+} \Leftrightarrow \mathrm{R}_{\mathrm{CE}} \stackrel{+}{\mathrm{N}} \mathrm{H}\left(\mathrm{C}_{2} \mathrm{H}_{5}\right)_{2}
$$

It is known that the non-protonated chitosan, having unshared electron pair on the nitrogen atom is capable of forming donor bonds with coordination unsaturated transition metals [25]. Upon this, one can expect similar behavior of DEAE 23 due to presence of amino groups. Also, two deprotonated $-\mathrm{OH}$ groups of cellulose in the $\mathrm{C} 2$ and $\mathrm{C} 3$ position may act as a chelating ligand. The complexing process can be shown as:

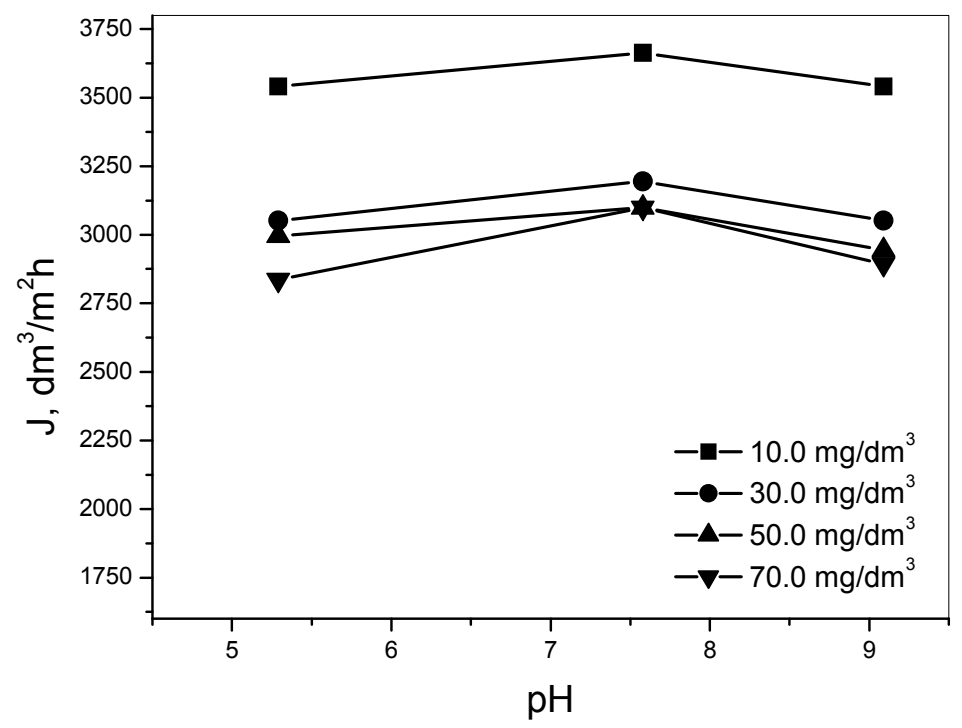

Figure 3. Effect of $\mathrm{pH}$ and different concentration of $\mathrm{Pb}$-ion on the flux (Versapor membrane, $\left.p=300 \mathrm{kPa}, c_{D E A E}=75 \mathrm{mg} \mathrm{dm^{-3 }}\right)$. 


$$
\mathrm{M}^{2+}+n \mathrm{R}_{\mathrm{CE}}-\mathrm{N}\left(\mathrm{C}_{2} \mathrm{H}_{5}\right)_{2} \Leftrightarrow \mathrm{M}\left(\mathrm{R}_{\mathrm{CE}}-\mathrm{N}\left(\mathrm{C}_{2} \mathrm{H}_{5}\right)_{2}\right)_{n}^{2+}
$$

The combination of Eqs. (3) and (4) yield:

$$
\mathrm{M}^{2+}+n \mathrm{R}_{\mathrm{CE}}-\stackrel{+}{\mathrm{N} H}\left(\mathrm{C}_{2} \mathrm{H}_{5}\right)_{2} \Leftrightarrow \mathrm{M}\left(\mathrm{R}_{\mathrm{CE}}-\mathrm{N}\left(\mathrm{C}_{2} \mathrm{H}_{5}\right)_{2}\right)_{n}^{2+}+n \mathrm{H}^{+}
$$

According to Eq. (5), an increase in $\mathrm{pH}$ enhances the formation of the complexes, thus increasing retention coefficient. As seen from Figure 4, this is experimentally confirmed.

It can be seen that the metal ion rejection efficiency was increased with $\mathrm{pH}$ increase, reaching maximal values at $\mathrm{pH} \geq 7$. The rejection of metals depends strongly on the $\mathrm{pH}$ due to the higher binding with the polymeric ligands at higher $\mathrm{pH}$ values. As $\mathrm{pH}$ increases, the affinity and stability of DEAE 23-metal complexes increases.

With low initial metal ion concentration $(10 \mathrm{mg} / \mathrm{L})$, the metal rejection coefficient was 99.9 at all investigated $\mathrm{pH}$. At high metal ion concentration $(70 \mathrm{mg} / \mathrm{L})$, the majority of $\mathrm{Pb}(\mathrm{II})$ ions had been bound with available amino and hydroxyl groups of DEAE23. Remaining of $\mathrm{Pb}(\mathrm{II})$ ions in form of free microsolute were able to go across membrane pores and leave the system in the permeate stream, and the rejection efficiency decreased (Figure 4). High retention at $\mathrm{pH} 9.0$ even at high concentration of $\mathrm{Pb}(\mathrm{II})$ ions can be attributed to possibility for precipitation of metal hydroxide.

\section{Effects of $\mathrm{pH}$ and complexing agent concentration}

The effects of $\mathrm{pH}$ on the flux and rejection of the metal ions from aqueous solutions using polyacrilic microfiltration membrane are shown in Figures 5 and 6, respectively. The increase of concentration of complex- ing agent resulted in the increase of flux, as shown in Figure 5.

In Figure 6 the rejection coefficient of $\mathrm{Pb}(\mathrm{II})$ ions in the absence and presence of DEAE 23 (in different concentrations) as a function of $\mathrm{pH}$ is shown. It is evident that at $\mathrm{pH}<5.0$ free $\mathrm{Pb}$ (II) ions pass through membrane, but are almost completely retained at $\mathrm{pH}>$ $>9.0$ due of the precipitation of the metal hydroxide.

The rejection coefficient is higher in the presence of complexing agent, DEAE 23, than in the absence of ligand. Metal removal increased when larger concentrations of polymer were used. In general, the increase in the concentration of water-soluble polymeric ligands in wastewater makes the process of complexation-microfiltration more efficient. This increase of polymer concentration usually leads to an increment in the concentration polarization phenomenon close to the surface of the membrane, which can also be related to a higher metal removal, but also a slight decrease of flux at $\mathrm{pH}>7.0$ (Figure 5). Also, by increase of ligand concentration up to $110.0 \mathrm{mg} \mathrm{dm}^{-3}$, rejection coefficient increased to $90 \%$ already at $\mathrm{pH}<6.0$. It can be concluded that at low lead concentrations $\left(50.0 \mathrm{mg} \mathrm{dm}^{-3}\right)$, lead ions almost completely bind to the DEAE 23 molecules (Figure 6).

\section{CONCLUSIONS}

Effects of various operating parameters on efficiency of lead removal from water were investigated.

- It has been shown that complexation-microfiltration can be applied for removal of lead ions using DEAE 23 as a complexing agent.

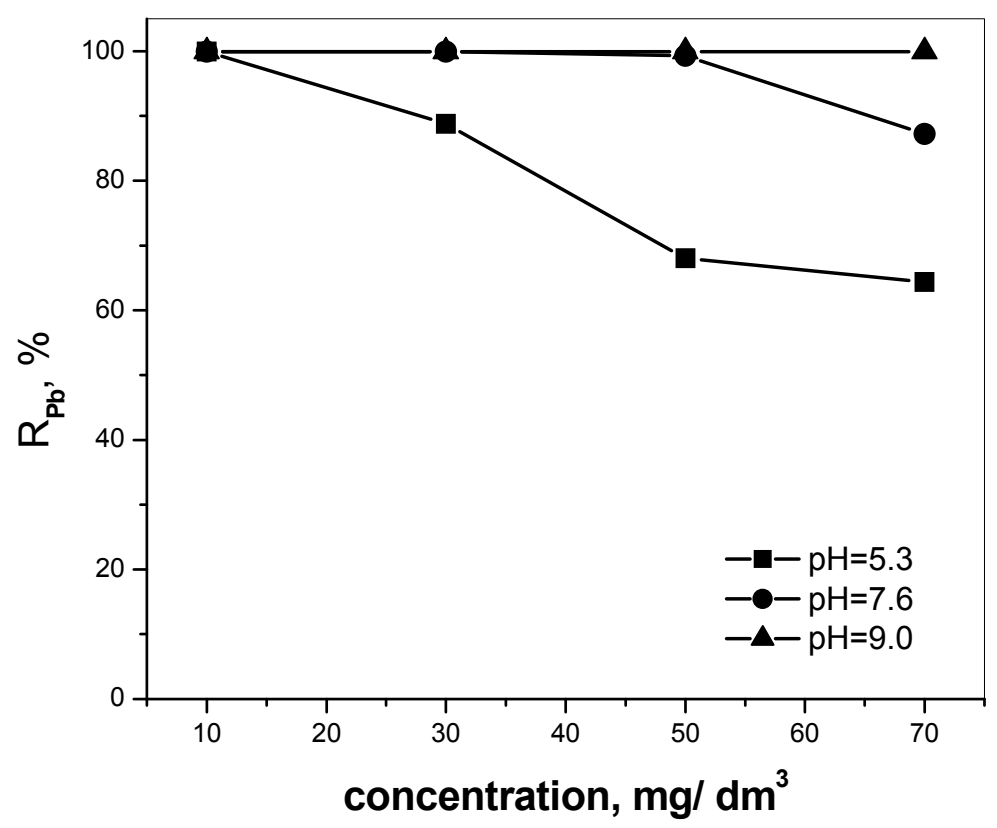

Figure 4. Effect of $\mathrm{pH}$ and different concentration of Pb-ion on the retention (Versapor membrane, $p=300 \mathrm{kPa}, c_{D E A E}=75 \mathrm{mg} \mathrm{dm}{ }^{-3}$ ). 


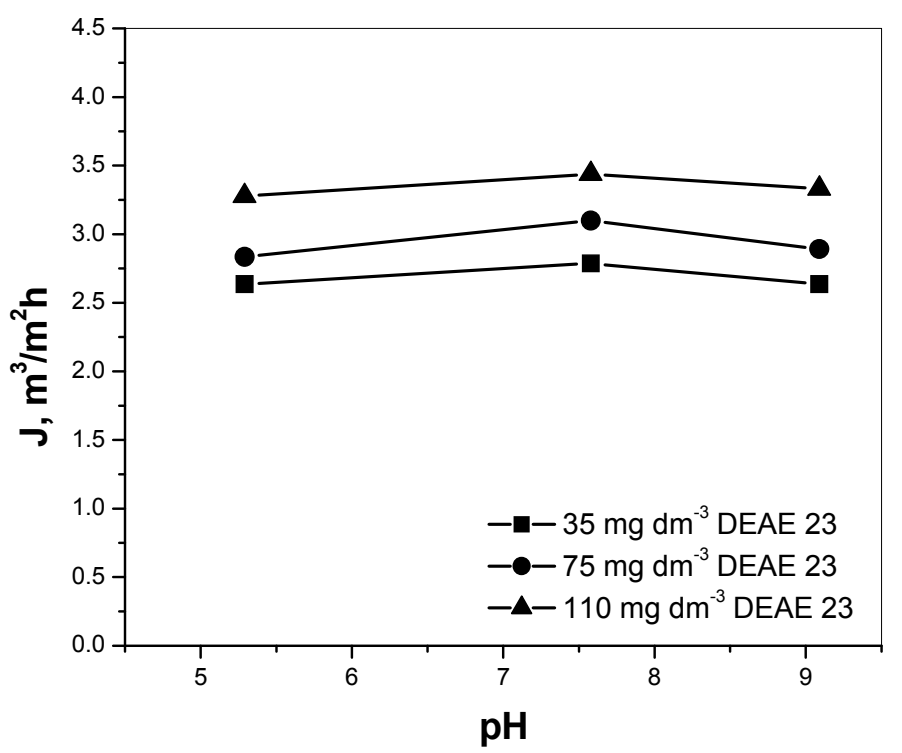

Figure 5. Effect of $\mathrm{pH}$ and different concentration of DEAE 23 on the flux (Versapor membrane, $p=300 \mathrm{kPa}, c_{P b}=50.0 \mathrm{mg} \mathrm{dm}$ ).

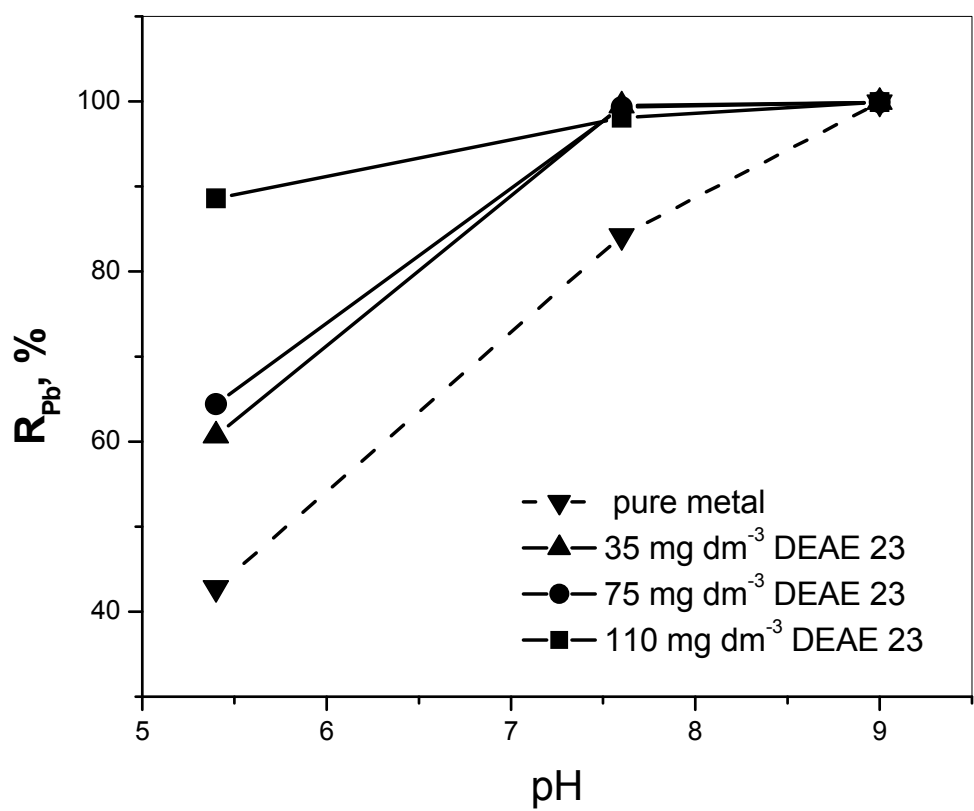

Figure 6. Effect of $\mathrm{pH}$ and different concentration of DEAE 23 on the retention (Versapor membrane, $p=300 \mathrm{kPa}, c_{P b}=50.0 \mathrm{mg} \mathrm{dm^{-3 }}$ ).

- The efficiency of the process strongly depends on $\mathrm{pH}$ values, whether in the presence of complexing agent or not. In alkaline conditions, retention coefficients above $99 \%$ were attained.

- The retention coefficient also depends on concentration of ions in the solution. The retention coefficient smoothly increases with increasing concentration of complexing agent, due to higher amount of metal ions bound to DEAE 23.

- For developing a practical process, other important factors, such as other membranes, regeneration of macroligand, effect of ionic strength, etc., must be studied.

\section{Acknowledgement}

The authors would like to acknowledge Laboratoire de Génie des Procédés, Faculté d'CEnologie, Bordeaux for providing ultrafiltration cell used in this study. This work was financially supported by the Ministry of Education and Science (Project number ON 172007).

\section{REFERENCES}

[1] F. Fu, Q. Wang, Removal of heavy metal ions from wastewaters: A review, J. Environ. Manage. 92 (2011) 407-418. 
[2] S.M.C. Ritchie, D. Bhattacharyya, Membrane-based hybrid processes for high water recovery and selective inorganic pollutant separation, J. Hazard. Mater. 92 (2002) 21-32.

[3] H. Zhou, D.W. Smith, Advanced technologies in water and wastewater treatment, J. Environ. Eng. Sci. 1 (2002) 247-262.

[4] K.E. Geckeler, Polymer-metal complexes for environmental protection. Chemoremediation in the aqueous homogeneous phase, Pure Appl. Chem. 73 (2001) 129-136 .

[5] G.M. Geise, H.S. Lee, D.J. Miller, B.D. Freeman, J.E. McGrath, D.R. Paul, Water purification by membranes: The role of polymer science, J. Polym. Sci., B 48 (2010) 1685-1718.

[6] K.S. Katsoufidou, D.C. Sioutopoulos, S.G. Yiantsios, A.J. Karabelas, UF membrane fouling by mixtures of humic acids and sodium alginate: fouling mechanisms and reversibility, Desalination 264 (2010) 220-227.

[7] K. Kawano, K. Hamaguchi, S. Masuda, T. Tomida, Binding properties of a water-soluble chelating polymer with divalent metal ions measured by ultrafiltration. Poly $(\alpha-$ acethylaminoacrylic acid), Ind. Eng. Chem. Res. 41 (2002) 5079-5084.

[8] B.S.Kim, S.-T.Lim, Removal of heavy metal ions from water by cross-linked carboxymethyl corn starch, Carbohyd. Polym. 39 (1999) 217-223.

[9] P. Canizares, A. Perez, R. Camarillo, J. Llanos, M.L. Lopez, Selective separation of $\mathrm{Pb}$ from hard water by a semicontinuous polymer-enhanced ultrafiltration process (PEUF), Desalination 206 (2007) 602-613.

[10] R. Molinari, P. Argurio, T. Poerio, G. Gullone, Selective separation of copper(II) and nickel(II) from aqueous systems by polymer assisted ultrafiltration, Desalination 200 (2006) 728-730.

[11] D. Zamariotto, B. Lakard, P. Fievet, N. Fatin-Rouge, Retention of $\mathrm{Cu}(\mathrm{II})$ - and $\mathrm{Ni}(\mathrm{II})$-polyaminocarboxylate complexes by ultrafiltration assisted with polyamines, Desalination 258 (2010) 87-92.

[12] M.K. Aroua, F.M. Zuki, N.M. Sulaiman, Removal of chromium ions from aqueous solutions by polymer-enhanced ultrafiltration, J. Hazard. Mater. 147 (2007) 752$-758$.

[13] A. Aliane, N.Bounatiro, A.T. Cherif, D.E. Akretche, Removal of chromium from aqueous solution by complexation - ultrafiltration using a water-soluble macroligand, Water Res. 35 (2001) 2320-2326.
[14] A. Vijayalakshmi, D. Lawrence Arockiasamy, A. Nagendran, D. Mohan, Separation of proteins and toxic heavy metal ions from aqueous solution by CA/PC blend ultrafiltration membranes, Sep. Purif. Technol. 62 (2008) 32-38 .

[15] R.-S. Juang, R.-C. Shiau, Metal removal from aqueous solutions using chitosan-enhanced membrane filtration, J. Membrane Sci. 165 (2000) 159-167.

[16] J. Llorens, M. Pujolà, J. Sabaté, Separation of cadmium from aqueous streams by polymer enhanced ultrafiltration: a two-phase model for complexation binding, J. Membrane Sci. 239 (2004) 173-181.

[17] E. Guibal, Interactions of metal ions with chitosan-based sorbents: a review, Sep. Purif. Technol. 38 (2004) 43-74.

[18] S. Petrov, V. Nenov, Removal and recovery of copper from wastewater by a complexation-ultrafiltration process, Desalination 162 (2004) 201-209.

[19] M. Soylak, U. Divrikli, S. Saracoglu, L. Elci, Membrane filtration - atomic absorption spectrometry combination for copper, cobalt, cadmium, lead and chromium in environmental samples, Environ. Monit. Assess. 127 (2007) 169-176.

[20] S. Mimoune, F. Amrani, Experimental study of metal ions removal from aqueous solutions by complexationultrafiltration, J. Membrane Sci. 298 (2007) 92-98.

[21] D.J. Ennigrou, L. Gzara, M.R.B. Romdhane, M. Dhahbi, Retention of cadmium ions from aqueous solutions by poly(ammonium acrylate) enhanced ultrafiltration, Chem. Eng. J. 155 (2009) 138-143.

[22] N. Uzal, A. Jaworska, A. Miskiewicz, G. ZakrzewskaTrznadel, C. Cojocaru, Optimization of $\mathrm{Co}^{2+}$ ions removal from water solutions via polymer enhanced ultrafiltration with application of PVA and sulfonated PVA as complexing agents, J. Colloid Interface Sci. 362 (2011) 615-624.

[23] D.W. O'Connell, C.O. Birkinshaw, T.F. Dwyer, Heavy metal adsorbents prepared from the modification of cellulose: a review, Bioresour. Technol. 99 (2008) 6709$-6724$.

[24] K. Trivunac, S. Stevanovic, Removal of heavy metal ions from water by complexation-assisted ultrafiltration, Chemosphere 64 (2006) 486-491.

[25] R.S. Juang, R.C. Shiau, Metal removal from aqueous solutions using chitosan-enhanced membrane filtration, J. Membrane Sci. 165 (2000) 159-167. 


\title{
IZVOD
}

\section{UTICAJ RADNIH PARAMETARA NA EFIKASNOST UKLANJANJA JONA OLOVA POMOĆU KOMPLEKSIRAJUĆE-MIKROFILTRACIONOG PROCESA}

\author{
Katarina V. Trivunac, Slavica M. Stevanović
}

Univerzitet u Beogradu, Tehnološko-metalurški fakultet, Beograd, Srbija

\section{(Naučni rad)}

Industrijske otpadne vode ne mogu se prečistiti konvencionalnim postupcima za prečišćavanje vode jer sadrže jone metala, posebno toksičnih, teških metala, kao i druga hemijska jedinjenja koja su biološki nerazgradiva, što destruktivno deluje na mikroorganizme koji su aktivni u procesu prirodnog prečišćavanja i procesima sekundarnog prečišćavanja. U zavisnosti od tipa industrije, u industrijskih otpadnim vodama mogu se naći različite štetne, opasne i toksične supstance. Zagađujuće materije se mogu naći u vodi u rastvornom obliku, u obliku jona ili molekula, koloida, suspenzija i mogu biti adsorbovane na čvrstim telima. Da bi se rešili novi izazovi i bolje iskoristili ekonomski izvori, različite tehnologije su predložene, testirane i primenjene u procesu obrade vode. Među njima, tehnologija membranske filtracije se pokazala veoma uspešna za uklanjanje širokog opsega potencijalnih zagađujućih materija i veoma pogodna u procesima pripreme vode za piće i procesima obrade industrijskih otpadnih voda. $U$ radu je proučavan kompleksirajuće-mikrofiltracioni proces za uklanjanje jona olova. Mikrofiltracija je membranska tehnika koja se vrlo uspešno koristi za koncentrisanje i frakcionisanje rastvora makromolekula (proteina, poliaminokiselina i viših šećera). Poznato je da se ovom tehnikom ne mogu ukloniti joni teških metala iz vode. Međutim, ukoliko se joni teških metala vežu sa makromolekulima nekih od navedenih jedinjenja, onda se ova metoda može uspešno primenjivati. Cilj rada je bio da se na modelu otpadne vode, koja sadrži jone olova, odredi optimalni odnos koncentracije kompleksirajućeg sredstva i metala kao i optimalna pH vrednost rastvora. Mikrofiltracija je vršena u ćeliji sa mešanjem. Kao kompleksirajuće sredstvo izabrana je dietilaminoetil celuloza. Separacija formiranih kompleksa je vršena na Versapor mikrofiltracionim membranama. Koncentracija jona metala posle mikrofiltracije je određena atomskom apsorpcionom spektroskopijom. Ispitani su uticaji količine kompleksirajućeg sredstva, koncentracije jona metala, $\mathrm{pH}$ vrednosti rastvora i radnog pritiska na fluks i koeficijent zadržavanja. Eksperimentalni rezultati su pokazali značajan uticaj $\mathrm{pH}$ na koeficijent zadržavanja. Povećanje pH kao i količine kompleksirajućeg sredstva omogućili su postizanje veoma visokog koeficijenta zadržavanja jona olova od $99 \%$.

Ključne reči: Kompleksirajuće-mikrofiltracioni proces • Uklanjanje olova • Tretman vode $\bullet$ Dietilaminoetil celuloza 